International Journal of Current Advanced Research

ISSN: O: 2319-6475, ISSN: P: 2319-6505, Impact Factor: 6.614

Available Online at www.journalijcar.org

Volume 7; Issue 4(L); April 2018; Page No. 12151-12160

DOI: http://dx.doi.org/10.24327/ijcar.2018.12160.2131

Research Article

\title{
EFFECT OF INJECTOR OPENING PRESSURE ON DAIRY SCUM BIODIESEL OPERATED DIESEL ENGINE
}

\author{
Manjunath Channappagoudra*1., Ramesh $\mathrm{K}^{2}$ and Manavendra.G ${ }^{3}$ \\ 1,2Department of Mechanical Engineering, U.B.D.T College of Engineering, Davangere, Karnataka, India \\ ${ }^{3}$ Department of Mechanical Engineering, B.I.E.T, Davangere, Karnataka, India
}

\section{A R T I C L E I I F O}

Article History:

Received $16^{\text {th }}$ January, 2018

Received in revised form $9^{\text {th }}$

February, 2018 Accepted $24^{\text {th }}$ March, 2018

Published online $28^{\text {th }}$ April, 2018

\section{Key words:}

Dairy scum biodiesel, Diesel engine, Injector opening pressure, emissions

\begin{abstract}
A B S T R A C T
The applications of diesel engines are more as they have more output power and thermal efficiency. But their emissions effect the environment and human being health. Hence there is a lot of scope to search for alternative fuels which promise better performance and emission behaviors of internal combustion (IC) engines. In this regard dairy scum oil methyl ester (DSOME) is a promising sustainable substitute fuel for conventional diesel engines. The standard diesel engine parameters are optimum for diesel but not for DSOME. The present investigation made a effort to use dairy waste scum as a potential source of alternative fuel for diesel engine. In first phase of work, different blends of DSOME (B10, $\mathrm{B} 20, \mathrm{~B} 30$ and $\mathrm{B} 100)$ are prepared and studied their effect on diesel engine performance and emission characteristics. From the study it's observed that DSOME-B20 exhibits improved performance and emission characteristics among other blends hence it is optimized and carried for further investigation. In second phase of work injector opening pressure (IOP) of the standard engine is modified from 210 bar to 240 bar in step of 10 bar $(210,220,230$ and 240 bars) to study the performance, emission and combustion characteristics of the diesel engine. From the experimental results it's revealed that increasing the IOP from 210 bar to 230 bar with DSOME-B20, brake thermal efficiency (BTE) is increased while brake specific flue consumption (BSFC), $\mathrm{CO}$, and $\mathrm{HC}$ emissions are reduced however, NOx (oxides of nitrogen) is increased marginally. The combustion parameters namely heat release rate (HRR) and cylinder pressure are enhanced significantly with DSOME-B20 at 230 bar IOP. Based on experimental results it's conclude that 230 bar IOP is the optimum for DSOME-B20 fuel blend operation in diesel engine.
\end{abstract}

Copyright $(2018$ Manjunath Channappagoudra., Ramesh K and Manavendra. G. This is an open access article distributed under the Creative Commons Attribution License, which permits unrestricted use, distribution, and reproduction in any medium, provided the original work is properly cited.

\section{INTRODUCTION}

Diesel engines are the most efficient prime movers. Development of alternative fuels with comparable properties to diesel is in need to protect the environment and energy security [1]. As the oil and gas resources are going to end in few decades, crop based oils are the key alternative fuels to conventional petroleum fuels. The use of Biohydrogen in IC engines will play the key role in upcoming days [2]. Dependency on fossil fuels can be reduced by using biodiesel and its blends in diesel engine [3]. Biodiesel is renewable, nonhazardous and has good lubrication properties. But have some draw backs like higher specific gravity, viscosity and lower heating value compare to petro-diesel [4]. Biodiesel production could be increased with proper utilization of raw material resource at precise time with additional care [5]. The properties of used palm oil biodiesel are within ASTM standards.

\footnotetext{
*Corresponding author: Manjunath Channappagoudra Department of Mechanical Engineering, U.B.D.T College of Engineering, Davangere, Karnataka, India
}

Hence used palm oil biodiesel and its blends can be used as a substitute fuel in direct injection (DI) diesel engine [6]. There is a lot of scope for research for automotive manufacturers as the biodiesel has higher viscosity and density hence investigations on effect of fuel spray, combustion and pollution formation is highly pronounced as the higher viscosity of biodiesel tends to alter the injection spray characteristics, resulting in fuel hits on the piston bowl surfaces [7]. The utilization of biodiesel in engines could consequences the considerable reduction in particulate matter, $\mathrm{HC}$ and $\mathrm{CO}$ emissions except $\mathrm{NOx}$ [8]. For biodiesel run engine GHG emissions are lower [9]. The diesel engine offers greater power output, thermal efficiencies and longer life when compared to the SI engine, whereas diesel engine emissions will affect on human health by providing polluted air. Therefore search for ecco-friendly fuels are highly marked for diesel engines [10].

Challenges associated with biodiesel industry development, biodiesel policy and biodiesel utilization in automobile sector could be resolved, biodiesel will be the future fuel and it can be applied widely in automobile sector and it will be more convenient fuel [11].The biodiesel can be produced by various 
vegetable oils and animal fat oils like, animal tallow, castor oil, algae oil, cashew nut oil, Camelina sativa Oil and they can utilized in the conventional diesel engine with no engine modification. The emissions levels such as $\mathrm{CO}$, HC Smoke, $\mathrm{CO}_{2}$ are less compare to petro-diesel engine hence biodiesel and its blends can be considered as suitable substitute fuel for standard diesel with reduced air pollution [12-18]. There will be reduction in $\mathrm{HC}$ and Soot and Nox in engines operated with biodiesel [19]. The physical properties of biodiesel are quite similar to the conventional diesel fuel [20]. The smoke concentrations are less with biodiesel operation than diesel. But lower No emissions can be achieved with the application of exhaust gas recirculation operated with biodiesel, but it is not for diesel operation. [21]. As the injection pressure increase soot emissions are decreased but NOx emissions increased for biodiesel and its blends compare to diesel. EGR (exhaust gas recirculation) and injection timing variation could be beneficial to reduce NOx not for CO, THC [22]. At higher compression ratio of 18 operated with $100 \%$ biodiesel will exhibits the reduction in $\mathrm{HC}$ and $\mathrm{CO}$ compares to the diesel [23].The oxides of nitrogen can be decreased injecting water into the combustion cavity of diesel engine [24].The application of additive in biodiesel blends reduced the emission and improved the combustion and performance of the engine [25]. The amide-functionalized MWCNTs-CeO2 catalyst with diesel/biodiesels blends can substitute the pure diesel without any adverse effect in the engine performance [26]. Mustard oil methyl ester with magnetite ferrofluid will give the positive impact by enhancing engine performance and reducing $\mathrm{HC}, \mathrm{CO}, \mathrm{NOx}$ and smoke. [27]. 4\% ethanol addition to the diesel increases the output power and efficiency while decreases the fuel consumption in addition the higher compression ratio of 21 improved the engine efficiency [28]. $\mathrm{CO}, \mathrm{HC}$ and smoke emissions are loared for all test fuels with the coated and uncoated piston. However, NOx emissions are raised when engine is coated. The noise decreased is observed with ceramic coating. Heat releases are close to each other in both coated and uncoated engines. [29]. As the biodiesel share is increased there is reduction in performance, ignition delay and peak pressure but improves the emissions. Hence biodiesel is the alternative to the diesel. [30]. However, NOx and CO2 emission are enhanced in the coated engine. The lower blends of dual biodiesel (pongamia pinnata and neem oil) result in better engine performance and slightly higher in comparison petro- diesel. [31].

Different engine parameters can be modified to enhance engine performance. Various researchers are studied the performance of the engine with varying different engine parameters to improve the performance and emissions. The higher injector opening pressure of 240 bar improved the performance and emissions of the diesel engine operated with linseed methyl ester [32]. Guide vanes are installed at intake manifold to improve the engine performance and to reduce emissions with biodiesel run engine [33]. Engine alterations with different parameters like injector opening pressure (IOP), injection timing (IT) and compression ratio (CR) are auspicious to use biodiesels in engines to have improved performance [34]. The cylinder pressure HRR affected by water injection through inlet manifold with no adverse effect on fuel consumption [35]. Engine performance and exergy are improved with optimized heat exchanger designs [36]. Turbulence in cylinder could be increased with guide vane and tumble device for higher viscous biodiesels. [37]. The biodiesel production from the non-edible oils will improve rural economy, energy security and sustainable development and also these biodiesels operated engine efficiency can enhanced with aid of preheating of biodiesel using hot exhaust gases [38]. At maximum load, with increased blending ratio and higher compression ratio there would be decraement in $\mathrm{CO}, \mathrm{HC}$ emission. Lower blended with preheated palm oil can substitute the diesel fuel [39]. For $20^{\circ}$ bTDC retarded injection timing (IT) NOx, HC, CO are reduced while BTE and smoke enhanced when compared to baseline injection timing of the engine. [40]. 20\% Annona biodiesel run engine with increased $\mathrm{CR}$ and IT had resulted enhanced BTE and reduced BSFC, CO and $\mathrm{HC}$ emissions [41]. The fast combustion is resulted when the IOP is increased and there is serious reduction of soot at part and low engine speeds but there will be considerable increment in NOx it can be controlled by EGR [42]. The engine power can be increased by increasing the IOP hence there is reduction in smoke and BSFC [43]. The higher IOP 230 bar had shown improved performance and reduced emissions namely $\mathrm{HC}, \mathrm{CO}$ and smoke operated with used transformer oil (UTO) when compared to 200 bar IOP [44].

\section{Dairy scum waste a source of alternative fuel}

Biodiesel production cost and disposal problem of dairy waste scum can be solved by producing biodiesel prom dairy waste scum. The properties of scum biodiesel are within ASTM standards thus it can be productively used in diesel engines [45]. Biodiesel properties like specific gravity, kinematic viscosity, calorific value, flash point are determined using Fourier Transform Infrared Spectroscopy (FTIR) and they are within ASTM standard limits hence dairy scum biodiesel can be used in the diesel engine [46, 47].

The performance and emission behaviors of diesel engines depends on various parametrs like, IT, IOP, Piston bowl shape, different holes nozzle, fuel spray formation, air swirl, organic or nano additive, piston surface coating, EGR application, compression ratio, injection timing, water injection (in intake manifold, direct injection into combustion cavity and emulsification with water), etc. The biodiesel operated diesel engine performance can also be improved by providing better swirl with desired combustion chamber geometry [53]. Higher atomization can be attained when the injection pressure increased in engine injection system. From the literature it is found that there are limited investigations on diesel engine operated dairy scum biodiesel. Hence it's directed to investigate effect of different injector opening pressure (210, 220, 230 and 240 bar IOP's) on diesel engine performance, combustion and emission characteristics with DSOME-B20 biodiesel blend operation at constant speed.

\section{MATERIALS AND METHODS}

\section{Dairy scum biodiesel production}

White color and semisolid dairy waste scum (Fig.1) is collected from diary effluent treatment unit and heated it up to $50-60^{\circ} \mathrm{C}$ to converting (melting) into liquid and permitted to settle down to remove lower unwanted aqueous phase. Upper layer of oil is separated and filtered to remove dissolved wastes from the scum oil. 


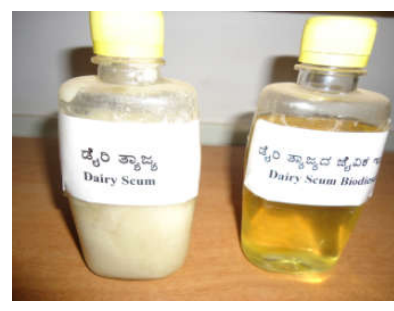

Fig 1 Dairy scum and scum oil biodiesel.

Schematic flow diagram of dairy scum biodiesel production plant is shown in Fig.2. Dairy scum oil, methanol and potassium hydroxide are the used main raw materials for biodiesel production with different equipments namely stirrer, electric heater, thermostat, stainless steel reactor, biodiesel and glycerin tanks, flow control valves and control panel.

The separated dairy scum oil is transesterified using transesterification method where scum oil is mixed with methanol and $\mathrm{KOH}$ (potassium hydroxide) catalyst in a reactor with agitator (stirrer) for 2 hours at $60^{\circ} \mathrm{C}$ and then it is kept for 12 hour to obtain biodiesel and glycerin. Then bottom settled glycerin is collected in a glycerin tank. Three times produced crude biodiesel is ished with water to remove acids, soaps and residual catalyst. At the end, transesterified biodiesel is heated to $110^{\circ} \mathrm{C}$ to remove the dissolved water particles which are present in the biodiesel. The procedure is repeated until getting clear biodiesel.

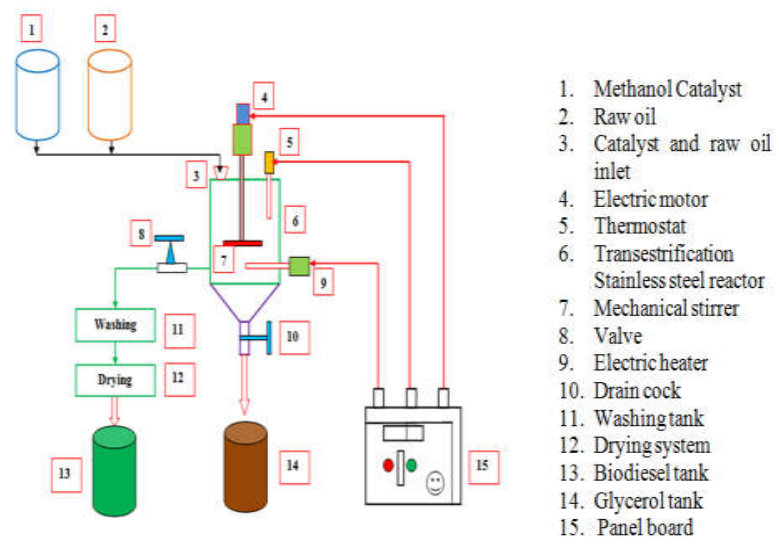

Fig 2 Biodiesel production process

\section{Biodiesel properties}

Efficient use of fuel in diesel engines can achieve by selecting right fuel with right proportion. In this study, dairy scum biodiesel and its different blends like B10, B20, B30 and B100 are used for experimentation. The properties of biodiesel and its blends are determined as per ASTM-6751 standard. Hydrometer is used to determine the specific gravity of the fuel and bomb calorimeter is used to determine heating value of fuel blends. To measure the viscosity of the fuels Redwood viscometer is used. Pensky-Martens equipment is used to determine the Flash and fire points of the different fuel blends in the laborotary.

Table 1 Properties of biodiesel fuel blends.

\begin{tabular}{ccccccc}
\hline Properties & $\begin{array}{c}\text { Methods } \\
\text { IS 1448 }\end{array}$ & Diesel & B10 & B20 & B30 & B100 \\
\hline Density $\left(\mathrm{kg} / \mathrm{m}^{3}\right)$ & P:16 & 830 & 833 & 840 & 844 & 870 \\
Viscosity at $40^{\circ} \mathrm{C}(\mathrm{cSt})$ & $\mathrm{P}: 25$ & 2.9 & 2.94 & 2.98 & 3.15 & 4.36 \\
Calorific value $(\mathrm{kJ} / \mathrm{kg})$ & $\mathrm{P}: 6$ & 43000 & 42935 & 40890 & 40012 & 38012 \\
Flash Point $\left({ }^{\circ} \mathrm{C}\right)$ & $\mathrm{P}: 69$ & 50 & 55 & 58 & 62 & 130 \\
Fire point $\left({ }^{\circ} \mathrm{C}\right)$ & $\mathrm{P}: 69$ & 60 & 66 & 68 & 75 & 142 \\
\hline
\end{tabular}

\section{Experimental setup}

The experiments are conducted on Kirloskar (TV1) single cylinder, 4 strokes, diesel engine (Fig.3 \& Fig.4). The engine specifications are given in Table 2. The experimental set up consist of a diesel engine, ECU, Exhaust gas analyzer, burette and stopwatch, digital manometer, data acquisition system, Chromel Alumel (K-Type) thermocouples. "Engine soft LV" software is used for online combustion analysis. Piezosensor and crank angle sensors which are mounted into the engine head and flywheel are used to measure the combustion pressure. An orifice fitted to air box is used to measure amount of air flow. The test engine is coupled to an electric dynamometer and overheating of dynamometer is prevented using water circulation. Speed of the engine is maintained constant as $1500 \mathrm{rpm}$ throughout the work. The engine is operated with pure diesel to have baseline readings. There after engine is fueled with different DSOME blends to conduct the experiments then average of three readings are considered for analysis. Optimization of fuel blend is made in first phase and optimization of injection timing is made in second phase of work. Then optimized fuel blend from first phase is carried to second phase of experimental work to study the effect of IOP on engine performance. In this work IOP of standard engine (210 bar) is modified and experiments are carried out for different injector opening pressures at different loads. At the end of experiment the DSOME-B20 fuel is replaced with diesel and engine is kept running for some time to remove DSOME-B20 fuel from injection system before turn off. Airrex Automotive Emission Analyzer HG-540 is used to determine the exhaust emissions, like Hydrocarbons (HC), Carbon Monoxide (CO), and Oxides of Nitrogen (NOx).

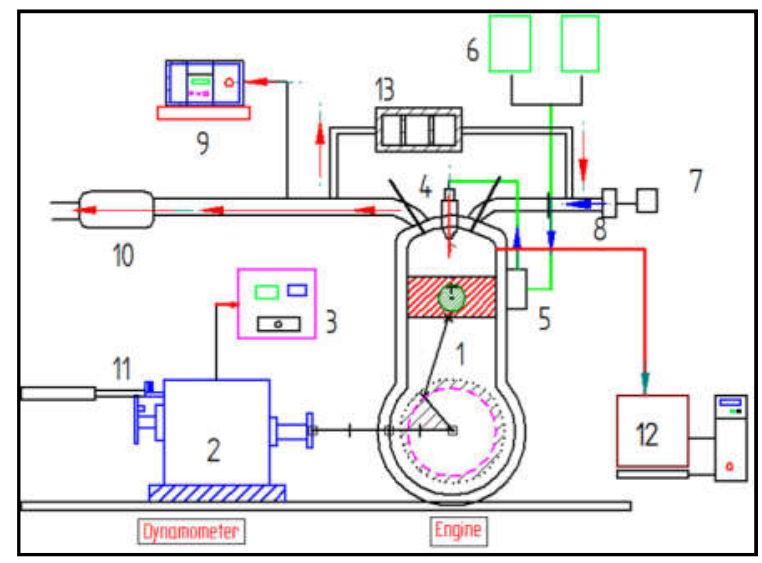

Fig 3 Schematic diagram of diesel engine test rig.

1. Kirloskar TV1 engine, 2. Eddy Current Dynamometer, 3. Control Panel, 4 Fuel Injector, 5.Fuel pump, 6.Fuel tank, 7. Air filter, 8.air stabilizing tank 9. Exhaust gas analyzers, 10. Exhaust gas silencer, 11. Crank encoder, 12. Data acquisition system

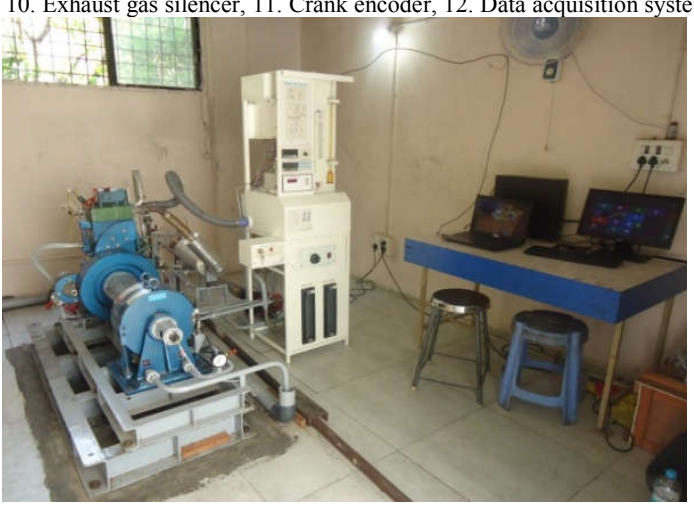

Fig.4 Photograph of experimental set up. 
Table 2 Engine specifications.

\begin{tabular}{ll}
\hline Parameters & Specifications \\
\hline Engine suppliers & Apex Innovations Pvt. \\
& Ltd \\
Type & TV1 (Kirloskar) \\
Cubic capacity & $661 \mathrm{cc}$ \\
Bore and stroke length & $87.5 \mathrm{~mm} \mathrm{X} \mathrm{110} \mathrm{mm}$ \\
Injector opening pressure & $210 \mathrm{bar}$ \\
Rated power & $3.5 \mathrm{~kW}$ at $1500 \mathrm{rpm}$ \\
Injection timing & $23^{0} \mathrm{bTDC}$ (diesel) \\
No. of cylinder/stroke & one $/$ four \\
Compression ratio & 17.5 \\
Dynamometer & Eddy current \\
Software used & Engine soft \\
\hline
\end{tabular}

The standard engine IOP (210 bar) is varied from 210 bar to 240 bar in step of 10 bar $(210,220,230$ and 240 bar) and aimed to optimize and study the effects of IOP on diesel engine performance, combustion and emission characteristics of diesel engine fueled with optimized fuel blend. The experiments are conducted from zero to full load conditions in steps of $0,20,40,60,80$ and $100 \%$ loads. Manufacturer specified parameters injection timing (23.deg.bTDC), Compression ratio (CR-17.5), nozzle geometry (3 hole, 0.3 mm diameter) and piston shape (Hemispherical) are kept same throughout the experimental work. In this present study engine performance (BTE, BSFC), combustion (heat release rate, peak pressure, cumulative heat release rate and rate of pressure rise) and emissions ( $\mathrm{HC}, \mathrm{CO}$ and $\mathrm{NOx}$ ) are determined and compared with standard diesel.

\section{RESULTS AND DISCUSSION}

\section{Phase-1: Optimization of DSOME blend}

In this first phase of work experiments are carried to optimize the best blend ratio in B10, B20, B30 and B100 and optimized blend among above is carried for further investigations.

\section{Brake thermal efficiency}

Fig. 5 shows the comparison of BTE with brake power for petroleum diesel and different dairy scum biodiesel blends. From the test results it is noticed that BTE of dairy scum is lesser than pure diesel for all loads it could be due to lower heating value, higher specific gravity and higher viscosity of the dairy scum biodiesel. BTE reduces when biodiesel percentage is increased with diesel it is attributed to reduced heating value of biodiesel blends.

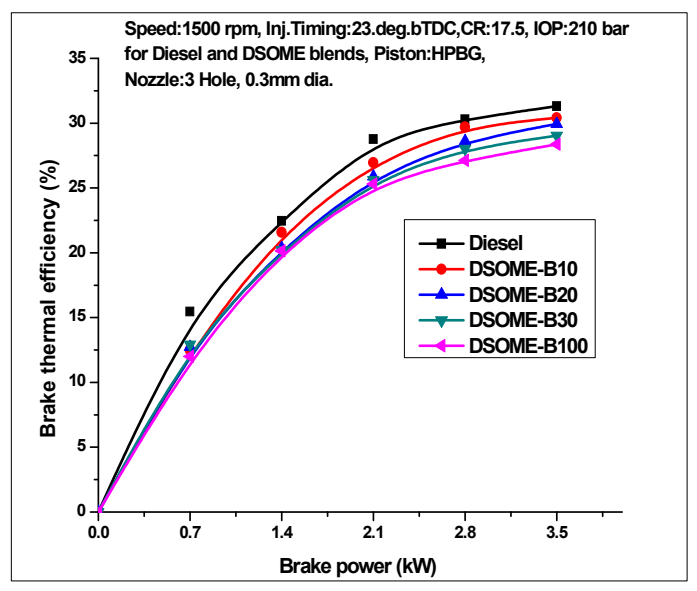

Fig 5 Brake thermal efficiency verses brake power.

From the experimental results is seen that the blend B10 has BTE of $30.42 \%$ and B20 has BTE of $29.93 \%$ respectively at maximum load and they are closer when compared to BTE of B30 (29.04\%) and B100 (28.37\%). Compare to blend B30 and $\mathrm{B} 100, \mathrm{~B} 20$ blend has higher BTE hence it is optimized

\section{Brake specific fuel consumption}

Fig.6 represents the variations of BSFC with brake power. The trend shows that the BSFC increases with the biodiesel blend ration in diesel. This may be attributed to the lower heating values of and higher viscosity of the biodiesel. The BSFC for neat diesel is lesser among all blends it may be attributed to higher calorific value and lower viscosity and specific gravity of the diesel fuel contributes complete combustion. The blends $\mathrm{B} 30$ and B100 have higher fuel consumption when compared to $\mathrm{B} 10$ and $\mathrm{B} 20$. The reason may be admission of more fuel into cylinder to produce same out power of diesel as the biodiesel blends have lower heating value, higher viscosity and density leads slow and incomplete combustion. BSFC results for Diesel, B10, B20, B30 and B100 are found to be 0.29, $0.304,0.320,0.341$, and $0.352 \mathrm{~kg} / \mathrm{kW} . \mathrm{hr}$ respectively at maximum load. The BSFC of B20 $(0.320 \mathrm{~kg} / \mathrm{kW} . \mathrm{hr})$ is closer to blend B10 $(0.304 \mathrm{~kg} / \mathrm{kW} . \mathrm{hr})$ among other blends.

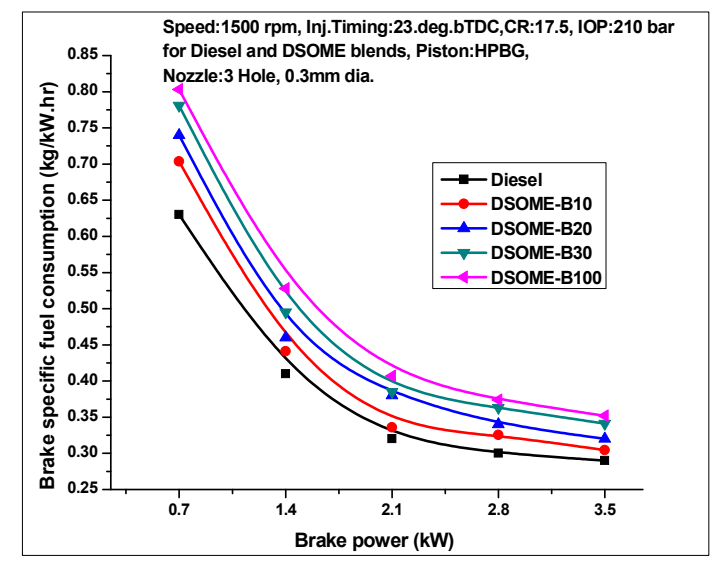

Fig 6 Brake specific fuel consumption verses brake power.

\section{Hydrocarbons emission}

Fig.7 shows the distinction of HC emission with brake power for petro diesel and different dairy scum biodiesel blends. The $\mathrm{HC}$ emission is lower for dairy scum biodiesel operation when compared to petroleum diesel. The reason may be more oxygen content in biodiesel contributes the better combustion.

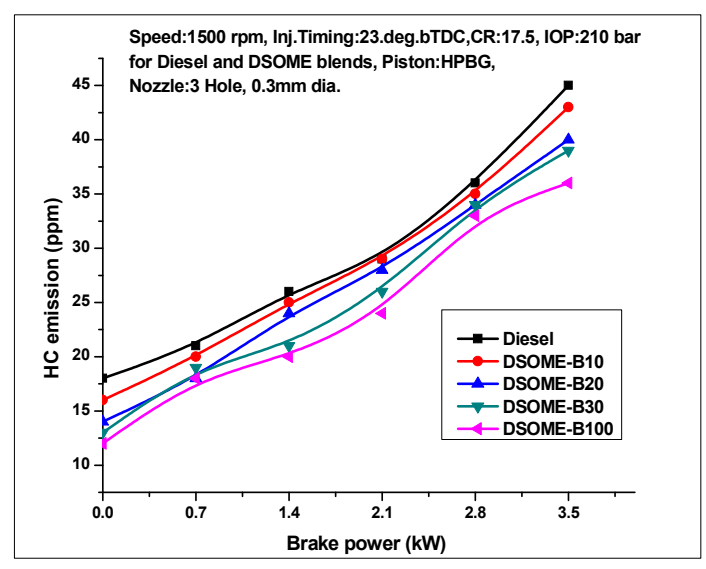

Fig 7 HC emission verses brake power.

At maximum load the blends B100 and B30 shown the lesser $\mathrm{HC}$ emissions of $36 \mathrm{ppm}$ and $39 \mathrm{ppm}$ among other blends it could be due to more inherent oxygen presence in the higher 
proportion of biodiesel tends improved and clean burning. Study reveals that $\mathrm{B} 10$ has higher $\mathrm{HC}$ emissions of $43 \mathrm{ppm}$ than $\mathrm{B} 20 \mathrm{HC}$ emission of $40 \mathrm{ppm}$ at maximum load.

\section{Carbon monoxide emission}

The comparison of $\mathrm{CO}$ emissions with brake power for neat diesel and dairy scum biodiesel blends are depicted in Fig.8. Biodiesel and their corresponding blends have lower $\mathrm{CO}$ emission than the conventional diesel as they have more oxygen content leads better oxidation and improved combustion as compared to diesel. It can be seen from graph that at beginning $\mathrm{CO}$ decreased with increasing load because of at zero load temperature of cylinder might be too less and later increased stridently up to maximum load. At full load $\mathrm{CO}$ emissions for Diesel, B10, B20, B30 and B100 are 0.089, $0.081,0.076,0.069$, and $0.062 \%$ respectively. The result clears that $\mathrm{CO}$ decrease with increased biodiesel blend concentration. The B100 and B30 have lower CO emissions followed by DSOME-B20. From the above results it's clear that B20 blend has lesser $\mathrm{CO}$ of $0.076 \%$ when compared to B10 of $0.081 \%$.

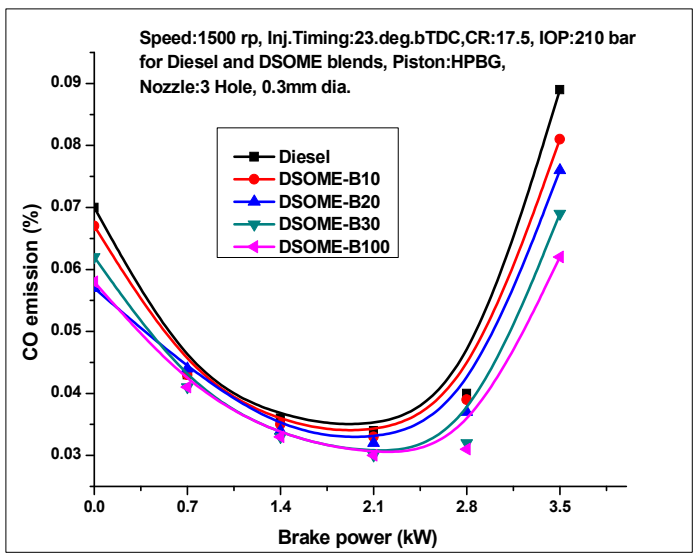

Fig $8 \mathrm{CO}$ emission verses brake power.

\section{Oxides of nitrogen emission}

Fig.9 shows the variations of oxides of nitrogen with brake power for standard Diesel and dairy scum biodiesel blends. Comparatively NOx is higher for biodiesel blends than petrodiesel over the entire load range. It may due to higher temperature and HRR during premixed combustion phase as biodiesel blends have more oxygen content compare to diesel leads improved combustion. The NOx level is higher for B100 compared to B10, B20 and B30 blends. The reason may be better combustion rate due to more homogeneous air-fuel mixing rate tends to better combustion at power stroke. From the study results, it could be seen that the blend B100 generated the highest nitrogen oxides when compared to other blends. At 100\% load, NOx emissions for Diesel, B10, B20, $\mathrm{B} 30$ and B100 are found to be 961, 976, 1006, 1021, $1085 \mathrm{ppm}$ respectively.

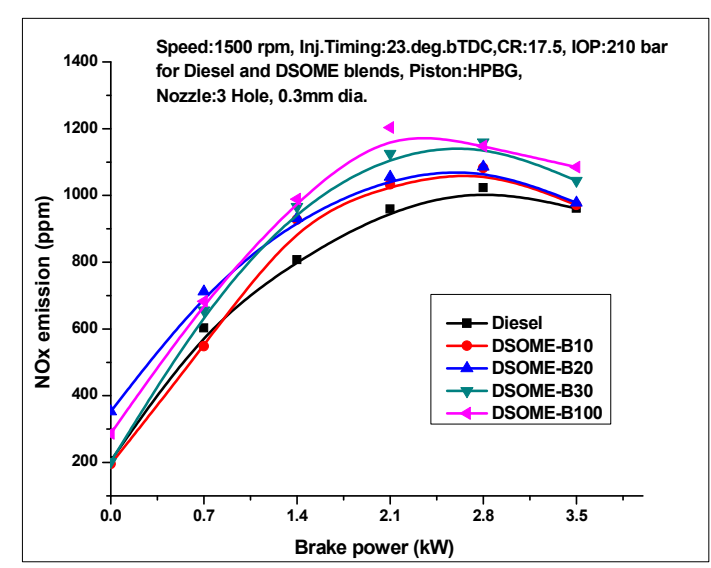

Fig 9 NOx emission verses brake power.

\section{Phase-2: Optimization of Injector opening pressure}

\section{Brake thermal efficiency (BTE)}

The variation of BTE with brake power is shown in Fig.10. BTE is increased as the IOP increased the reason might be the improved atomization, vaporization; better air-fuel mixing leads better combustion [52]. At 230 bar IOP enhanced air fuel mixing is observed during higher loads at compression process leads maximum BTE however it is lesser than diesel. This might be higher viscosity, low volatility, improper atomization and lower calorific value of DSOME-B20 than that of diesel. The maximum BTE of DSOME-B20 at 230 bar pressure is $30.55 \%$ and it is near to the petro-diesel (210 bar) BTE of $31.32 \%$ at full load condition. However DSOME-B20 with 240 bar IOP BTE decreased compared to 230 bar IOP for all loads. The reason might be, too increased IOP will reduced the fuel droplet size, hence too finer (very small size) fuel droplets have lower momentum and relative velocity leads incomplete combustion by its own combustion products. And also Higher IOP has low depth penetration, delayed ignition and more fuel consumption at full load because of their smaller droplet size $[44,48,49,50]$. However, if the IOP is too high ignition delay becomes shorter hence probability of air-fuel mixing rate will be lower leads decreased burning rate and increased emissions in the engine [51]. The BTE for Diesel, IOP 210 bar, 220 bar, 230 bar and 240 bars are found to be 31.32, 29.63, 29.94, 30.55 , and $27.97 \%$ respectively at full load condition.

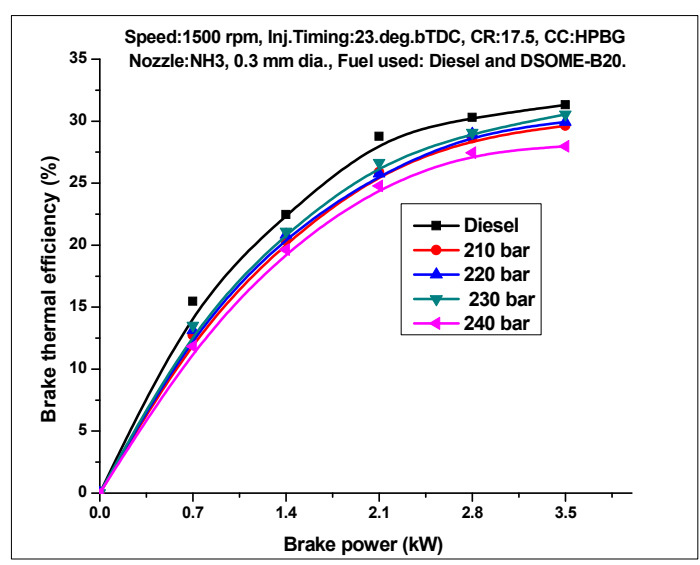

Fig.10 Brake thermal efficiency verses brake power. 


\section{Brake specific fuel consumption (BSFC)}

The BSFC with brake power for different IOP operated with DSOME-B20 is shown in Fig.11. From study it is noticed that at full load the BSFC is decreased with an increase in IOP. The BSFC of DSOME-B20 is higher than diesel it may be due to the lower calorific value of biodiesel. From the experimental results it revealed that at full load the BSFCs for Diesel, 210 bar, 220 bar, 230 bar, and 240 bar IOP's are 0.290, 0.320, $0.310,0.30$ and $0.330 \mathrm{~kg} / \mathrm{kW}$.h respectively. With an increase in IOP from 210 to 240 bar, the BSFC is increased from 0.320 to $0.33 \mathrm{~kg} / \mathrm{kW}$-hour fueled with DSOME-B20 which is attributed to lower calorific value and lesser momentum of smaller size fuel droplets hence reduction of fuel-air mixing rate in the burning leads incomplete combustion. The BSFC for 230 bar IOP is $0.30 \mathrm{~kg} / \mathrm{kW}$.hr which is near to diesel and lower than 210 bar, 220 bar and 240 bar IOP. Hence 230 bar IOP for is optimized for DSOME-B20.

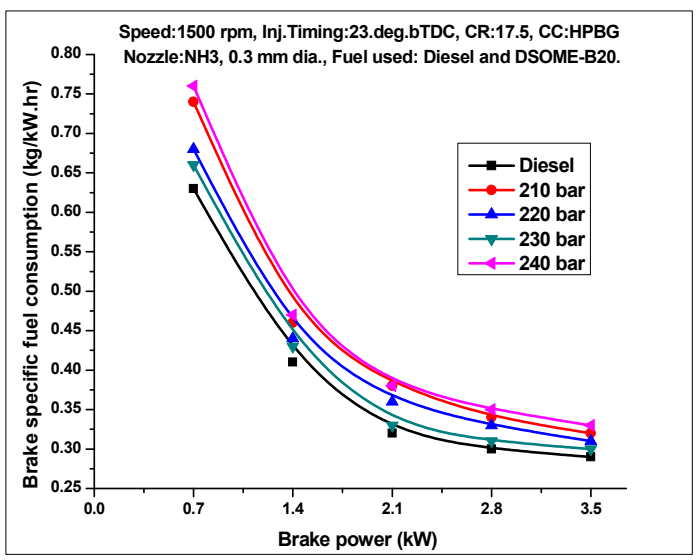

Fig 11 Brake specific fuel consumption verses brake power.

\section{Hydrocarbons (HC) emission}

Fig.12. depicts the distinction of $\mathrm{HC}$ emissions with brake power. The $\mathrm{HC}$ emission for conventional diesel operation had shown higher for all loads compare to the DSOME-B20 because of lower oxygen content in diesel compare biodiesel. For DSOME-B20 as the IOP increases the HC emission decreases, this may be attributed to improved atomization leads better air-fuel mixing rate and also the more availability of oxygen presence in biodiesel effects better oxidation and complete combustion. From study it is observed that $\mathrm{HC}$ emission for 230 bar IOP with DSOME-B20 is lower than the petroleum diesel for all loads, as diesel has higher hydrocarbons in it will increase $\mathrm{HC}$ emissions whereas presence of oxygen in DSOME-B20 might be advances the combustion process leads lowering the $\mathrm{HC}$ emissions. DSOME-B20 at 230 bar IOP HC emissions are minimum levels of $38 \mathrm{ppm}$ whereas at 240 bar IOP an increase in HC levels of $43 \mathrm{ppm}$ which may associated to local rich regions and some of the occupation of fuel droplet at crevice volume, finer spray, which reduces fuel droplet momentum resulting in poor combustion. [44, 48, 49]. The HC at full load reduces from 41 to $38 \mathrm{ppm}$ when IOP is increased from 210 bar to 230 bar. From the study the results revealed that the HC emissions for Diesel, 210 bar, 220 bar, 230 bar and 240 bar IOP's are found to be $45,41,40,38$, and 43 ppm respectively at full load.

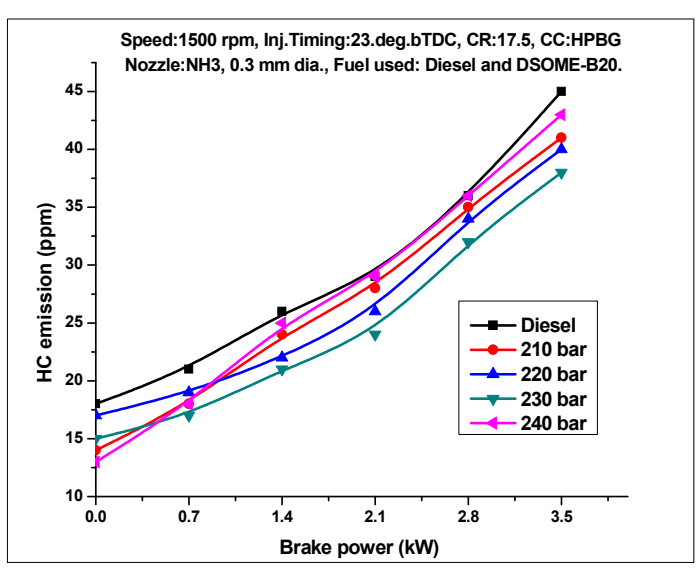

Fig $12 \mathrm{HC}$ emission verses brake power.

\section{Carbon monoxide (CO) emission}

The deviation of $\mathrm{CO}$ emissions with brake for different IOP's is shown in Fig.13. The higher combustion temperature would enhance the oxidation of carbon monoxide to form carbon dioxide hence results less $\mathrm{CO}$ emission. However indecent mixing of fuel with air and ineffective burning of fuel may results higher $\mathrm{CO}$ emission. Generally $\mathrm{CO}$ emission is lower for biodiesel fueled diesel engine it could be attributed to higher temperature and oxygen presence in biodiesel [16]. The $\mathrm{CO}$ emissions for diesel and DSOME-B20 fuels are lesser in lower engine loads and increased at higher engine load. This might be due to shorter oxygen with more fuel introduction into cylinder at higher loads. Whereas $\mathrm{CO}$ reduces with lower and medium loads because of rich oxygen and higher IOP [48, 49]. It is noticed that IOP of 230 bar with DSOME-B20 had resulted lesser $\mathrm{CO}$ emission as it has sufficient oxygen and improved fuel atomization led improved burning process. Hence there will be improved oxidation process as there is rapid mixing of air-fuel mixing and atomization in cylinder led to better combustion. At 240 bar IOP there appears to be an increase in $\mathrm{CO}$ which could be due to the too finer fuel spray leads reduced momentum of the fuel droplets results lower combustion, even at higher IOP higher boiling compounds may not break up [44, 48, 49]. The study shown the CO emission values for Diesel, 210 bar, 220 bar, 230 bar and 240 bar IOPs are 0.089, 0.076, 0.073, 0.071 and $0.078 \%$ respectively. From above results it is concluded that the $\mathrm{CO}$ of 230 bar IOP is lower than diesel and other IOPs.

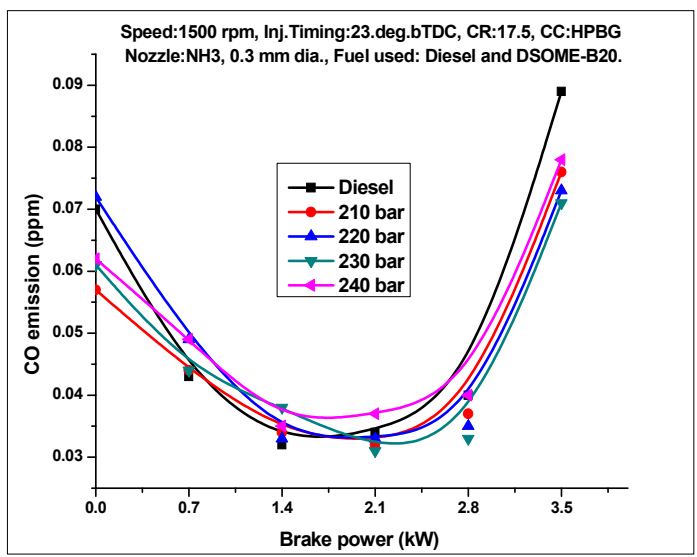

Fig $13 \mathrm{CO}$ emission verses brake power. 


\section{Oxides of nitrogen (NOx) emission}

Fig.14. represents the variation of NOx emission with different IOP. From the graph it clears that NOx emission is increased when the IOP is increased. This is attributed to dominant premixed combustion phase and complete combustion leads to increase in peak cylinder pressure and gas temperature inside the combustion chamber. The higher dairy scum biodiesel blend proportion with petro-diesel results higher NOx levels for all IOPs as they are rich in oxygen results improved burning $[16,48,49]$.The study revealed the nitrogen oxides for diesel, 210 bar, 220 bar, 230 bar and 240 bar IOPs are 961, 978, 983, 1021, $1014 \mathrm{ppm}$ respectively. Study reaveled that NOx emission for 230 bar is higher than diesel and other IOPs

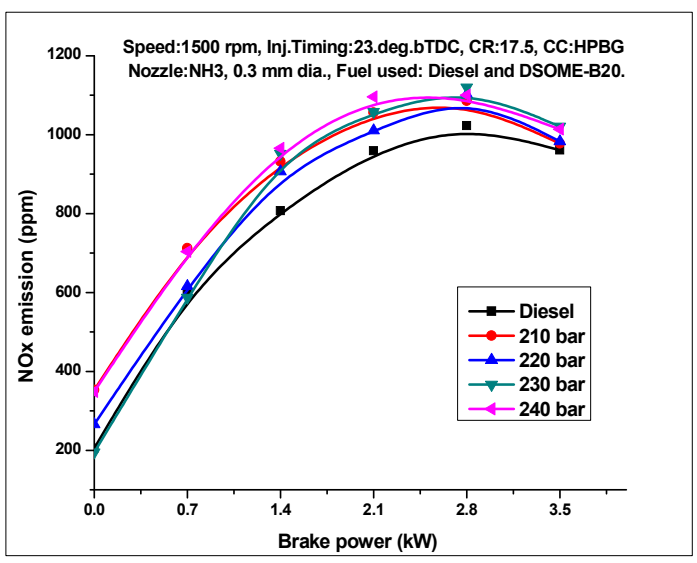

Fig 14 NOx emission verses brake power.

\section{Cylinder pressure}

Fig.15. depicts the deviation of cylinder pressure with crank angle for different IOP's at maximum load operated with DSOME-B20. Cylinder Pressure curve for different IOPs follow the trend same as Diesel pressure curve at rated 210 bar IOP. The cylinder pressure is highest with Diesel followed by DSOME-B20 at 230, 220, 210 and 240 bar IOP [48, 49]. As IOP increases combustion rate will be increased which leads in higher cylinder pressure. At 230 bar IOP pre mixed combustion phase is improved because of better fuel atomization, rapid vaporization, and fuel-air mixing in turn improved combustion. From study it's observed the peak pressure for Diesel, 210 bar, 220 bar, 230 bar and 240 bar IOP are found to be 53.63, 49.67, 49.81, 50.81 and 49.70 bar respectively. The peak pressure value of 230 bar IOP is greater than other IOPs but lower than diesel.

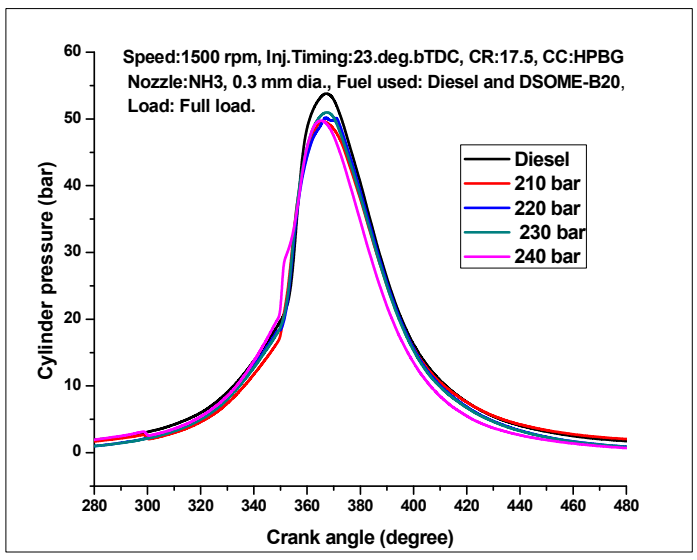

Fig.15 Cylinder pressure verses crank angle at 100\% load.

\section{Heat release rate (HRR)}

Fig.16. demonstrates the comparison of HRR with crank angle for different IOP's fueled with Diesel and DSOME-B20 at full load. It is observed that with DSOME-B20 the value of HRR for all IOPs are lower than neat diesel which might be attributed lower heating value, volatility and higher viscosity of DSOME-B20. Improved premixed heat release rates is noticed when the IOP is increased from 210 bar to 230 bar IOP which is due to improved fuel atomization and air-fuel mixing leads improved combustion. It is noticed that HRR increased as IOP increased from 210 bar of $57.14 \mathrm{~J} /$ crank angle to 230 bar of $62.22 \mathrm{~J} / \mathrm{crank}$ angle. The HRR for Diesel, $210 \mathrm{bar}, 220$ bar, 230 bar and 240 bar injector opening pressures are 65.43, $57.14,58.48,62.22$ and $54.83 \mathrm{~J} / \mathrm{crank}$ angle respectively at maximum load. From the experimental results it's clear that the 230 bar IOP resulted in higher heat release rate when compared to other IOPs whereas it is lesser than standard diesel.

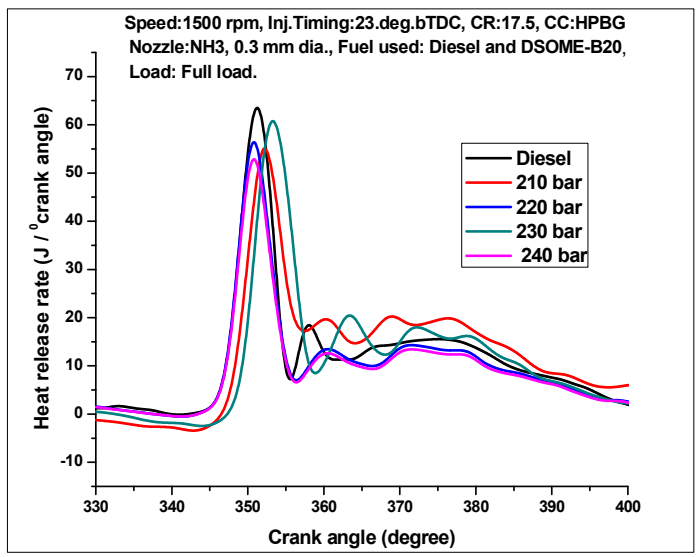

Fig 16 Heat release rate verses crank angle at $100 \%$ load.

\section{CONCLUSION}

In this study different DSOME blends are prepared (B10, B20, B30 and B100) and studied at different loads. Based on experimental results fuel blend is optimized and optimized fuel blend is carried further to study the influence of fuel IOP on performance, combustion and emission characteristics of diesel engine. IOP is varied from 210 to 240 bars in steps of 10 bar such as 210 bar, 220 bar 230 bar and 240 bar. The conclusions drawn from the study are summarized as below.

1. The B20 blend shows the improved BTE, BSFC among other blends except B10. BTE of B10 is higher and $\mathrm{BSFC}$ is lower when compared B20 whereas B10 HC, $\mathrm{CO}$ emissions are higher than $\mathrm{B} 20$. The $\mathrm{B} 20$ blend has lower $\mathrm{HC}$ and $\mathrm{CO}$ emissions than $\mathrm{B} 10$ and also its BTE is closer to $\mathrm{B} 10$. Hence $\mathrm{B} 20$ (DSOME-B20) is optimized and carried to the optimization of injector opening pressure.

2. When the IOP of engine is increased from 210 bar (manufacturer specified for diesel) to $230 \mathrm{bar}$ (modified for diesel) the BTE is increased from $29.63 \%$ to $30.55 \%$ while BSFC reduced from $0.320 \mathrm{~kg} / \mathrm{kW}$.h to 0.300 $\mathrm{kg} / \mathrm{kW} . \mathrm{h}$ respectively at maximum load.

3. From the emission study it is observed that, $\mathrm{HC}$ lowered from $41 \mathrm{ppm}$ to $38 \mathrm{ppm}$ and $\mathrm{CO}$ reduced from 0.076 to $0.071 \%$ whereas NOx increased from 978 to $1021 \mathrm{ppm}$ at full load. 
4. From the combustion study it's noticed that as the IOP increased from 210 bar to 230 bar an improvement occurs in the HRR, cylinder pressure. For 230 bar IOP peak pressure increase from 49.67 to 50.81 bar and HRR from $57.14 \mathrm{~J}$ to $62.2 \mathrm{~J} /$ crank angle when compared with standard engine IOP of 210 bar.

On whole, the blends of dairy scum biodiesel with diesel significantly reduced the $\mathrm{HC}$ and $\mathrm{CO}$ emissions whereas slightly increases the NOx. Among all blends B20 exhibits the improved performance and emission characteristics. It could be concluded that 230 bar IOP with DSOME-B20 is the best IOP as it revealed better performance and emission, combustion characteristics as compared to 210, 220 and 240 bar IOP's. For 240 bar IOP BTE, HRR and cylinder pressure are decreased while emissions like $\mathrm{HC}, \mathrm{CO}$ are increased when compared to 230 bar IOP it might be due to lesser fuel particle momentum and improper fuel distribution with too smaller fuel droplets leads poor combustion. From study it is concluded that 230 bar IOP with DSOME-B20 operation improves the engine performance, combustion and lowers the $\mathrm{HC}$, CO emissions. Hence 230 bar IOP is optimum for DSOME-B20 blend.

\section{Acknowledgements}

The authors are grateful to I \& D (Information and Demonstration on Biofuels) Centre, Biofuel Park Madenur, Hasan which is sponsored by Karnataka State Biofuel Development Board (KSBD), Govt. of Karnataka (India) for providing dairy scum oil biodiesel for research work. Authors would like to acknowledge the Managing Director of Apex Innovations, Sangli (India) for providing computerized experimental test setup to conduct the experiments.

\section{References}

1. B.K. Barnwal, M.P. Sharma, Prospects of biodiesel production from vegetable oils in India, Renewable and Sustainable Energy Reviews 9 (2005) 363-378.

2. A. DEMIRBAS. Future Fuels for Internal Combustion Engines. Energy Sources, Part A, 32:1273-1281, 2010.

3. Hifjur Raheman, Prakash C Jena and Snehal S Jadav. Performance of a diesel engine with blends ofnbiodiesel (from a mixture of oils) and high-speed Diesel. International Journal of Energy and Environmental Engineering 2013, 4:6.

4. Agarwal AK. Biofuels (alcohols and biodiesel) applications as fuels for internal combustion engines. Prog Energy Combust Sci 2007; 33:233-71.

5. Krishan K. Pandey, Namita Pragya, P.K. Sahoo. Life cycle assessment of small-scale high-input Jatropha biodiesel production in India. Applied Energy 88 (2011) 4831-4839.

6. H. Sharon, K. Karuppasamy, D.R. Soban Kumar, A. Sundaresan. A test on DI diesel engine fueled with methyl esters of used palm oil. Rnewable Energy 47 (2012)160-166.

7. Yoon SH, Park SH, Lee CS. Experimental investigation of the fuel properties of biodiesel and its blends at various temperatures. Energy Fuel 2008; 22:652-6.

8. Murari Mohon Roy, Wilson Wang, Justin Bujold. Biodiesel production and comparison of emissions of a DI diesel engine fueled by biodiesel-diesel and canola oil-diesel blends at high idling operations. Applied Energy 106 (2013) 198-208.
9. Avinash Kumar Agarwal, Abhay Shrivastava, Rajesh Kumar Prasad. Evaluation of toxic potential of particulates emitted from Jatropha biodiesel fuelled engine. Renewable Energy 99 (2016) 564-572.

10. John Kennedy Mwangi, Wen-Jhy Lee, Yu-Cheng Chang, Chia-Yang Chen, Lin-Chi Wang. An overview: Energy saving and pollution reduction by using green fuel blends in diesel engines. Applied Energy 159 (2015) 214-236.

11. Daming Huang, Haining Zhou, Lin Lin. Biodiesel: an Alternative to Conventional Fuel. Energy Procedia 16 (2012) 1874-1885.

12. Cengiz Öner, S_ehmus Altun. Biodiesel production from inedible animal tallow and an experimental investigation of its use as alternative fuel in a direct injection diesel engine. Applied Energy 86 (2009) 21142120.

13. Roopesh Kanwar, Pushpendra Kumar Sharma, Aditya Narayan Singh, Yadvendra Kumar Agrawal. Performance and Emission Characteristics of a Compression Ignition Engine Operating on Blends of Castor Oil Biodiesel-Diesel. J. Inst. Eng. India Ser. C, DOI 10.1007/s40032-016-0243-z.

14. M. Fatih Demirbas. Biofuels from algae for sustainable development. Applied Energy 88 (2011) 3473-3480.

15. Hamed Bateni, Keikhosro Karimi, Akram Zamani, Fatemeh Benakashani. Castor plant for biodiesel, biogas, and ethanol production with a biorefinery processing perspective. Applied Energy 136 (2014) 1422.

16. S. Vedharaj, R. Vallinayagam, W.M. Yang, S.K. Chou, K.J.E. Chua, P.S. Lee. Experimental and finite element analysis of a coated diesel engine fueled by cashew nut shell liquid biodiesel. Experimental Thermal Science 53 (2014) 259-268.

17. Nestor U. Soriano Jr, The environmental feasibility of algae biodiesel production Akash Narani. Evaluation of Biodiesel Derived from Camelina sativa Oil. J Am Oil Chem Soc (2012) 89:917-923, DOI 10.1007/s11746011-1970-1.

18. Tara Shirvani. The environmental feasibility of algae biodiesel production. Appl Petrochem Res (2012) 2:9395, DOI 10.1007/s13203-012-0015-5.

19. Su Han Park, Junepyo Cha, Chang Sik Lee. Impact of biodiesel in bioethanol blended diesel on the engine performance and emissions characteristics in compression ignition engine. Applied Energy 99 (2012) 334-343.

20. Nurul Atiqah Izzati Md Ishak, Ismail Ab Raman, Mohd Ambar Yarmo, Wan Mohd Faizal Wan Mahmood. Ternary phase behavior of water microemulsified diesel-palm Biodiesel. Front. Energy 2015, 9(2): 162169, DOI 10.1007/s11708-015-0355-9.

21. H. Song, B.T. Tompkins, J.A. Bittle, T.J. Jacobs. Comparisons of NO emissions and soot concentrations from biodiesel-fuelled diesel engine. Fuel 96 (2012) 446-453.

22. L. Labecki, L.C. Ganippa. Effects of injection parameters and EGR on combustion and emission characteristics of rapeseed oil and its blends in diesel engines. Fuel XXX (2012) XXX-XXX.

23. S V Channapattanaa, Kantharaj C, V S Shinde, Abhay A Pawar, Prashant G Kamble. Emissions and 
Performance Evaluation of DI CI - VCR Engine Fuelled with Honne oil Methyl Ester / Diesel Blends. Energy Procedia 74 (2015) 281 - 288.

24. Leszek Chybowski, Rafał Laskowski, Katarzyna Gawdzin'ska. An overview of systems supplying water into the combustion chamber of diesel engines to decrease the amount of nitrogen oxides in exhaust gas. $J$ Mar Sci Technol (2015) 20:393-405, DOI 10.1007/s00773-015-0303-8.

25. S. Vedharaj, R. Vallinayagam, W.M. Yang, S.K. Chou, P.S. Lee. Effect of adding 1,4-Dioxane with kapok biodiesel on the characteristics of a diesel engine. Applied Energy XXX (2014)-XXX.

26. Mortaza Aghbashlo, Meisam Tabatabaei, Pouya Mohammadi, Mehrdad Mirzajanzadeh, Mehdi Ardjmand, Alimorad Rashidi. Effect of an emissionreducing soluble hybrid nanocatalyst in diesel/ biodiesel blends on exergetic performance of a DI diesel engine. Renewable Energy 93 (2016) .353-368.

27. D. Yuvarajan1 M. Venkata Ramanan. Effect of Magnetite Ferrofluid on the Performance and Emissions Characteristics of Diesel Engine Using Methyl Esters of Mustard Oil. Arab J Sci Eng (2016) 41:2023-2030, DOI 10.1007/s13369-016-2060-3.

28. Atçilla Bçilgçin, Orhan Durgun, Zehra ,Sahçin. The Effects of Diesel-Ethanol Blends on Diesel Engine Performance. Energy Sources, 24:431-440, 2002.

29. Selman Aydin, Cenk Sayin, Hüseyin Aydin. Investigation of the usability of biodiesel obtained from residual frying oil in a diesel engine with thermal barrier coating. Applied Thermal Engineering 80 (2015) 212219.

30. Gaurav Paul, Ambarish Datta, Bijan Kumar Mandal. An Experimental and Numerical Investigation of the Performance, Combustion and Emission Characteristics of a Diesel Engine fueled with Jatropha Biodiesel. Energy Procedia 54 (2014) 455 - 467.

31. K. Srithar, K. Arun Balasubramanian, Marta Vivar, and Igor Skryabin. An Experimental Investigation on Diesel And Low Heat Rejection Engines With Dual Biodiesel Blends. International Journal of Green Energy, 10: 1041-1055, 2013.

32. Sukumar Puhan, R. Jegan, K. Balasubbramanian, G. Nagarajan. Effect of injection pressure on performance, emission and combustion characteristics of high linolenic linseed oil methyl ester in a DI diesel engine. Renewable Energy 34 (2009) 1227-1233.

33. S. Bari, Idris Saad. Effect of guide vane height on the performance and emissions of a compression ignition (CI) engine run with biodiesel through simulation and experiment. Applied Energy 136 (2014) 431-444.

34. Niraj Kumar, Varun, Sant Ram Chauhan. Evaluation of endurance characteristics for a modified diesel engine runs on jatropha biodiesel. Applied Energy 155 (2015) 253-269.

35. B. Tesfa, R. Mishra, F. Gu, A.D. Ball. Water injection effects on the performance and emission characteristics of a CI engine operating with biodiesel. Renewable Energy 37 (2012) 333-344

36. M. Hatami, M.D. Boot, D.D. Ganji, M. Gorji-Bandpy. Comparative study of different exhaust heat exchangers effect on the performance and exergy analysis of a diesel engine. Applied Thermal Engineering 90 (2015) 23-37.

37. S. Bari, P. J. G. Johansen, A. J. T. Alherz. Simulation of improvements to in-cylinder mixing of biodiesel with air by incorporating guide vanes into the air intake system. Procedia Engineering 105 (2015) 480 - 487.

38. N. Kapilan Natesan. The Enhancement of the Performance of a Biodiesel Operated Diesel Engine. Energy Sources, Part A, 35:1648-1656, 2013.

39. S. Nagaraja, K. Sooryaprakash, R. Sudhakaran. Investigate the Effect of Compression Ratio over the Performance and Emission Characteristics of Variable Compression Ratio Engine Fueled with Preheated Palm Oil-Diesel Blends. Procedia Earth and Planetary Science 11 (2015) 393 - 401.

40. S. Prasanna Raj Yadav, C.G. Saravanan, M. Kannan. Influence of injection timing on DI diesel engine characteristics fueled with waste transformer oil. Alexandria Engineering Journal (2015) 54, 881-888.

41. Senthil Ramalingam, Silambarasan Rajendran, Ravichandiran Nattan. Influence of injection timing and compression ratio on performance, emission and combustion characteristics of Annona methyl ester operated diesel engine. Alexandria Engineering Journal (2015) 54, 295-302.

42. D.T. Hountalas and D. A. Kouremenos, K. B. Binder, V. Schwarz, G. C. Mavropoulos. Effect of Injection Pressure on the Performance and Exhaust Emissions of a Heavy Duty DI Diesel Engine. 2003 SAE World Congress Detroit, Michigan, March 3-6, 2003.

43. M. Badami, P. Nuccio and G. Trucco. Influence of Injection Pressure on the Performance of a DI Diesel Engine with a Common Rail Fuel Injection System. International Congress and Exposition Detroit, Michigan, March 1-4, 1999, 1999-01-0193.

44. Pritinika Behera \& S. Murugan. Studies on a diesel engine fuelled with used transformer oil at different fuel injection nozzle opening pressures. International Journal of Ambient Energy, 2013, Vol. 34, No. 1, 5359.

45. P. Sivakumar, K. Anbarasu, S. Renganathan. Bio-diesel production by alkali catalyzed transesterification of dairy waste scum. Fuel 90 (2011) 147-151.

46. K.V. Yatish, H.S. Lalithamba, R. Suresh, S.B. Arun, P. Vinay Kumar. Optimization of scum oil biodiesel production by using response surface methodology. Process Safety and Environmental Protection $102(20$ $16) 667-672$.

47. H.V. Srikanth, J. Venkatesh, Sharanappa Godiganur, S. Venkateswaran, Bhaskar Manne. Bio-Based Diluents Improve Cold Flow Properties of Dairy Ished MilkScum Biodiesel. Renewable Energy 111 (2017) 168174.

48. Venkanna Krishnamurthy Belagur and Venkataramana C. Reddy. Effect Of Injector Opening Pressures On The Performance, Emission And Combustion Characteristics of Di Diesel Engine Running on Honne Oil And Diesel Fuel Blend. Thermal Science: Year 2010, Vol. 14, No. 4, pp. 1051-1061.

49. B.K.Venkanna, C.Venkataramana Reddy. Influence of injector opening pressures on the performance, emission and combustion characteristics of DI diesel engine running on calophyllum inophyllum linn oil (honne oil). 
International Journal of Renewable Energy, Vol. 6, No. 1, January - June 2011.

50. V. Ganeshan. Internal combustion Engine. Tata McGraw-Hill-2003, ISBN-0-07-049457-6.

51. Celikten, Ismet. 2003. "An Experimental Investigation of the Effect of the Injection Pressure on Engine Performance and Exhaust Emission in Indirect Injection Diesel Engines." Applied Thermal Engineering 23: 2051-2060.
52. Deepak Agarwal, Avinash Kumar Agarwal. Performance and emissions characteristics of Jatropha oil (preheated and blends) in a direct injection compression ignition engine. Applied Thermal Engineering 27 (2007) 2314-2323.

53. M. N Channappagoudra, Sunil Thaned, K. Ramesh, G.Manavendra. Optimization of Combustion Chamber Geometry for a Direct Injection Diesel Engine:A Review. International Journal of Engineering Research \& Technology (IJERT), Vol. 2 Issue 11, November 2013.

\section{How to cite this article:}

Manjunath Channappagoudra et al (2018) 'Effect of Injector Opening Pressure on Dairy Scum Biodiesel Operated Diesel Engine', International Journal of Current Advanced Research, 07(4), pp. 12151-12160.

DOI: http://dx.doi.org/10.24327/ijcar.2018.12160.2131 